\title{
Effect of bioactive compounds in ginger extract on cancer
} cell lines In vitro.

تأثير المركبات الحيوية الفعالة في مستخلص الزنجبيل Zingiber officinale على الخطوط الخلوية السرطانية خارج الجسم

Mohammed S. Mohammed Al-Zobaidi

Abd Al-Amer N. Galoob*

Muayad S. Shawkat

College of science/ University of Baghdad

*College of Science/ University of AL-Mustansiriya

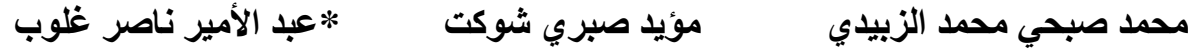

$$
\begin{aligned}
& \text { كلية العلوم / جأمعة بغداد } \\
& \text { * كلية العلوم / الجامعة المستنصرية }
\end{aligned}
$$

\section{Abstract}

This study was designed to detect the active compounds found in ethanolic crude extract of Zingeber officinale rhizome. Chemical detection of extract appeared that the ethanolic extract contain flavonoid, saponin, glycosids, phenols, resins, volatile oils, tannins, terpins and steroids while alkaloids and cumarines gave negative results. Different concentrations were prepared from ethanolic extract starting from (1-1000) $\mu \mathrm{g} / \mathrm{ml}$ to evaluate the cytotoxic effect of ethanolic extract on two malignant cell lines, human laryngeal carcinoma (HEP-2) cell line and murine mammary adenocarcinoma $(\mathrm{AMN}-3)$ cell line, exposure periods of cell lines were measured at $(24,48,72) \mathrm{hr}$ in a microtitration plate under complete sterile conditions. Results showed that, Ethanolic crude extract exhibited timedependent cytotoxic effect of all concentrations after exposure for $24 \mathrm{hr}$ on cancer and transformed cells lines, and the $100 \mu \mathrm{g} / \mathrm{ml}$ gave the highest inhibition rate for AMN-3 86.2\% after 24hr of exposure time and the cytotoxic effect of the extract started at lowest concentrations on HEP-2 cell line after $48 \mathrm{hr}$ of exposure reached which the best concentration $600 \mu \mathrm{g} / \mathrm{ml}$ gave the highest inhibition cell growth $73.4 \%$ after $48 \mathrm{hr}$ of exposure time.

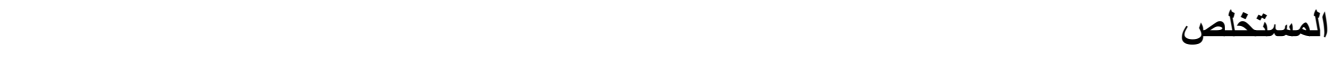

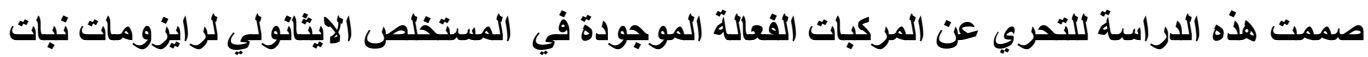

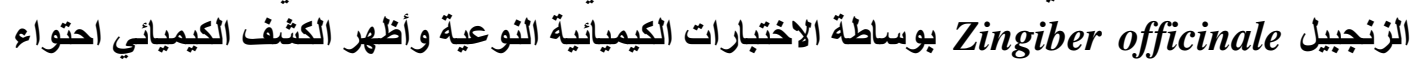

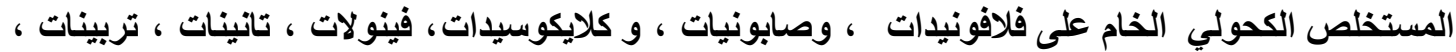

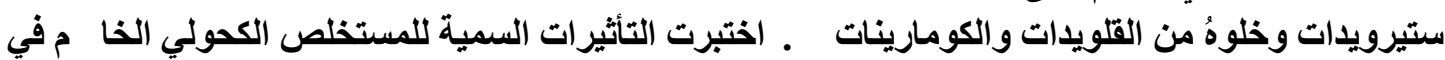
اثثين من الخطوط الخلوية العرطانية (خط سرطان الحنجرة البشري Hep-2 وخط خلايا سرطان الثاي الثاني الفاري AMN-3

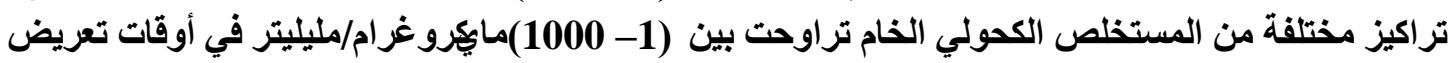
مختلفة (24،48،72) ساعة في المزرعة الخلوية بواسطة الاختبارات السمية بمعدل ثلاث مكررات لكل تركيز

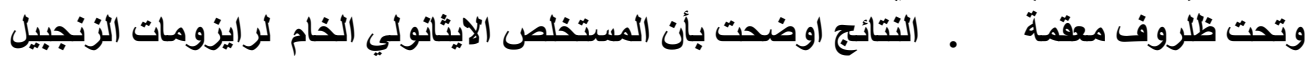
Z. officinale

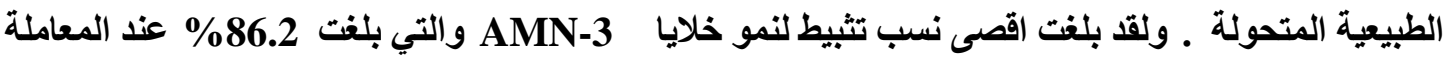
بتركيز 100 مايكروغرام/ مليليتر بعد 24 ساعة من وقت التعريض ، والتئنير السام للمستخلص الخام بدأ عند التراكيز الواطئة على خط خلايا

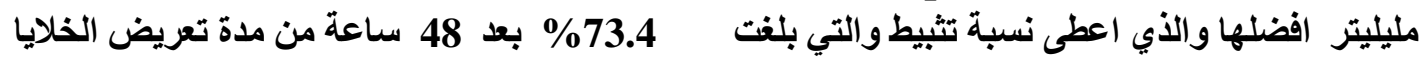
للمستخلص الخام ـ واظهر المستخلص الكحولي الخام سمية على خط خلايا والذي أعطى أعلى نسبة تثبيط إذ بلفت 94\% بعد 24 ساعة من وقت التعريض . 


\section{Introduction}

The idea of use the herbal medicine appeared clearly at the $17^{\text {th }} \mathrm{BC}$ when there was found tangible indication and manuscript about treatment by herbal medicine. The world health organization estimates that 76 million people died of cancer in 2005 and 84 million people will die in the next 10 years if action is not taken [1].

Many patients that do not response to conventional therapies and all oncologists often seek help in complementary alternative medicine treatment currently, complement alternative medicine cancer prevention strategies employ, herbs, foods, spices and specific nutrition's toward specific physiological pathway. Ginger (Zingiber officinale) is one of the most widely used herbs and food flavouring. Its neutraceutical properties have been interesting in food processing and the pharmaceutical industries [2].

Ginger has a long history of medicinal use for the treatment of a variety of human ailments including common colds, fever, rheumatic disorders, gastrointestinal complications, motion sickness, diabetes, cancer, etc [3].

The main pharmacological action of ginger and compound isolated from it includes immuno-modulatory, anti-tumorgenic, anti-inflamatory, anti-apoptosis, antihyperglycemic, anti-lipidemic and anti-emetic action [4]. The constituents of ginger are numerous and vary depending on the place of origin and whether the rhizomes are fresh or dry. Ginger is valued both for its aromatic, volatile compounds and by its spicy, pungent constituents. The latter principles are non volatile phenols with various side chains, the so called gingerols, shogaols and paradols. Researchers have identified at least 115 compounds within ginger. The pungency of fresh ginger is due primarily to the gingerols (a homologous series of phenols); whereas the pungency of dry ginger mainly results from shogaols (dehydrated forms of gingerols) [5]. 6gingerol is the most abundant constituent of fresh ginger which in vitro inhibits angiogenesis and may be useful in the treatment of tumors and other angiogenesisdependent diseases [6].

In addition, [7] showed the high cytotoxic activity of Zingiber officinale, Cucurbita maxima, Cucurbita pepo and Peganum harmala on Hep-2 (Human epidermoid laryngeal carcinoma) and RD (Rhabdomyosarcoma cell lines).

\section{Materials and methods}

\section{Rhizome collection}

Z. officinale dry rhizomes were collected from local markets. The rhizomes were washed several times with distilled water and air dried at room tempreture then grinded to coarse powder by electrical grinder and kept in clean plastic bottle.

\section{Preparation of ethanolic extract}

Fifty grams of $Z$. officinale rhizome powder were extracted with ethanol $250 \mathrm{ml}$ by soxhlet for 6 hours at $(45-50)^{\circ} \mathrm{C}$, the ethanolic extract was evaporated under vaccum to dryness by rotary evaporator at $40^{\circ} \mathrm{C}$ and kept at $4^{\circ} \mathrm{C}$ until use [8] .

\section{Detection of chemical compounds in ethanolic extract}

Chemical detection was done using different reagents as mentioned in [9] for the following compounds: Alkaloids, glycosides, flavonoids, tannins, Saponins, phenols, essential Oils, terpenes, steroids, and resins. 


\section{Cell lines}

Three cell lines were used (Hep-2, AMN-3) which supplied by Iraq Center for Cancer and Medical Genetic Research (ICCMGR), tissue culture unit, Baghdad, Iraq to estimate the cytotoxic effect of $Z$. officianale crude ethanolic extract which maintained in RPMI-1640 medium at concentrations (1, 6, 12.5, 25, 50, 75, 100, 200, $400,600,800,1000) \mu \mathrm{g} / \mathrm{ml}$ for $(24,48,72) \mathrm{hr}$ exposure time.

\section{Statistical analysis}

Data were analyzed by 2-way analysis of variance with ANOVA- test. Data are presented as means $\pm \mathrm{SD}$. The level of significance was $\mathrm{P}<0.05$ which used for analysis of variance test (ANOVA) [10].

\section{Results and discussion}

Table (1) shows the active compounds in the ethanolic crude extract of Z. officianale, these compounds are flavonoids, saponins, glycosids, phenols, resins, tannins, terpens and steroids. $\mathrm{pH}$ of the extract was 4.2 this value refers to acidic properties of the extract because of the absence of alkaloid. Z. officinale is characterized by pungent taste and aromatic smell due to the presence of terpenes including volatile oil [11].

Table (1): Detection of active compounds in Z.Officinale

\begin{tabular}{cccc}
\hline Active compound & reagent & indicator & Result of detection \\
Tannins & Ferric chloride (1\%) & Blue-green color & ++ \\
Glycosides & Kedd's reagent & Violet ring & ++ \\
Saponins & A- extract mixing & Thick foaming & ++ \\
Resins & Ethanol, boiling, D.W. & Turbidity & ++ \\
Flavonoids & potassium hydroxide & Dark color & +++ \\
Phenols & Ferric Chloride 1\% & Blue-Green color & +++ \\
Essential Oils & Filter paper +Extract+ UV & Rosy or pink & ++ \\
Terpine & Chlorophorm+non & pink color & ++ \\
& hydrous & & \\
Steroids & CH COOH+H $\mathbf{S O}_{4}$ & & + \\
& Similar for terpine reagent & Blue color & \\
\hline
\end{tabular}

+: Positive reaction

Cytotoxic effect of ethanolic crude extract of Ginger on AMN-3 cell line in vitro:

Figure (1) shows the cytotoxicity assay on AMN-3 cell line during $(24,48,72)$ hrs. The extract was found to reduce the viability of cell culture at three exposure time for all concentrations used. This inhibitory effect was reduced.

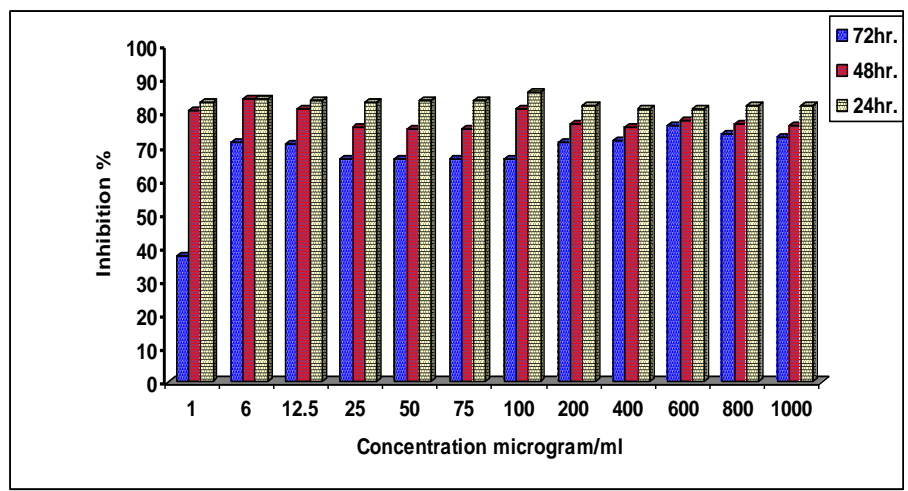

Figure (1): Shows the cytotoxic effects of crude ethanolic extract of Z.Officinale rhizome on AMN-3 cell lines in vitro during different exposure time 
After continuous exposure until reaching $72 \mathrm{hr}$ of exposure, where there was significant differences at level $(\mathrm{p}<0.05)$ for all concentrations $(1000,800,600,400$, $200,100,75,50,25,12.5,6,1) \mu \mathrm{g} / \mathrm{ml}$ compared with control. The highest percentage of inhibition was $86.2 \%$ at concentration $100 \mu \mathrm{g} / \mathrm{ml}$, O.D (0.051) after $24 \mathrm{hr}$. of exposure.

The ability to bind with plasma membrane receptor of AMN-3 cell differs according to the origin and type of cells. A variety of highly specific receptors molecules are integral component of the cell surface. These constitute recognition sites that receive chemical signal which are often transferred to the cell. Such signals may initiate a variety of chemical activities and may turn off ultimately signal specific genes [12].

It was suggested that 6-gingerol pungent ingredient of ginger has anti-bacterial, antiinflammatory, anti-tumor-promoting activities and inhibit angiogenesis and this plant may be useful in the treatment of tumors and other angiogenesis- dependent diseases [13].

Both the nutritive and non-nutritive components of the diet play a significant role in the inhibition of carcinogenic process. The non-nutritive constituents exert their anticarcinogenic effect by various mechanisms via:

1. By virtue of their anti-oxidant property.

2. Deactivating the carcinogens.

3. Or enhancing the tissue levels of protective enzymes in the body.

Toxic metabolites of harmful drugs and chemicals are detoxified by the body defense system. Phytochemicals found in turmeric, mustard and alliums' vegetables may act more than one way to confer their beneficial effect [14].

\section{Cytotoxic effect of ethanolic crude extract of Ginger on HEP-2 cell line in vitro}

The cytotoxicity results of crude extract of $Z$. officinale on HEP-2 cell line during (24, $48,72) \mathrm{hrs}$, were shown in Figure (3). These effects were begin after $24 \mathrm{hr}$ of exposure time of the cells to the extract, the extract showed low cytotoxicity on the cells in $24 \mathrm{hr}$. The highest inhibition were seen at $48 \mathrm{hr}$ of exposure time at the concentration $(1000,2000,4000) \mu \mathrm{g} / \mathrm{ml}$ and then decreased with decreasing the concentrations.

The cell inhibition was decreased at $72 \mathrm{hr}$ of exposure period, and this may be due to the exhausting of the media which leads to decrease cell viability. The differences during the different concentrations $(1000,400,200,75,25,1) \mu \mathrm{g} / \mathrm{ml}$ were significant at level $(\mathrm{p}<0.05)$ when compared with control treatment after $24 \mathrm{hr}$ of exposure time. No significant differences at level $(\mathrm{p}>0.05)$ were found between $(48,72) \mathrm{hrs}$ of exposure time except at concentrations $(600-6) \mu \mathrm{g} / \mathrm{ml}$ which gave a significant differences at level $(\mathrm{p}<0.05)$ when compared with control for $(48,72)$ hrs. The concentration $600 \mu \mathrm{g} / \mathrm{ml}$ O.D (0.057) gave the highest inhibition effect on cell growth which reached $73.5 \%$ after $48 \mathrm{hr}$ of exposure time 


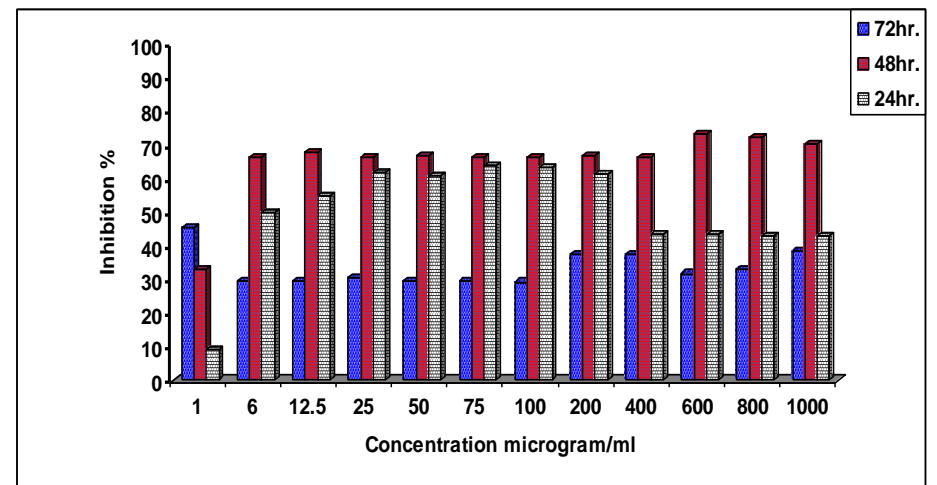

Figure (2): Cytotoxic effects of ethanolic crude extract of Z.Officinale rhizome on HEP-2 cell lines in vitro during different exposure time

$80 \%$ of inhibition effect could be obtained when treating HEP-2 cancer cell lines with ginger crude extract at concentrations from 1000-100 $\mu \mathrm{g} / \mathrm{ml}[15]$.

The inhibition activity of the extract against AMN-3 cell growth observed during long time of exposure at all concentrations while the effects against the growth of HEP-2 cell line were observed during short time of exposure at low concentrations. This can be attributed to sensitivity of AMN-3 cell and or may be due to the variation in the cytotoxic activity of active compounds in the extract according to different time of exposure.

Studies mentioned that AMN-3 cell line showed high sensitivity than Hep-2 when treated with crude extracts containing polyphenol and terpenoid which have cytotoxic effects on different cell line such as Hep-2 and AMN-3 cell line under different doses and exposure time [16].

Different constituents in ginger extract made it hypertonic solution and may cause dose-dependent osmotic shock to cancer cell lines [17].

The differences in Hep-2 response toward different treatments might indicate the presence or absence of specific cellular receptors in each type of cell lines; making the cells interacts at same concentration in different manners. Moreover the metabolic pathways in response to each treatment differed from one line to another. These facts were mentioned in different studies which investigated the effect of different plant extracts on several types of cell lines [18].

Antioxidants are compounds that can delay or inhibit the oxidation of lipids or other molecules by inhibiting the initiation or propagation of oxidative chain reactions. Ginger contains bioactive phenolic substances with potent antioxidative and chemopreventive properties [19]. The antioxidant activity of phenolic compounds is mainly due to their properties, which can play an important role in absorbing and neutralizing free radicals, quenching singlet and treble oxygen or decomposing peroxides. The phenolic compounds in many plant and vegetables, including ginger may contribute directly to antioxidative action. It is suggested that polyphenolic compounds have inhibitory effects on mutagenesis and carcinogenesis in humans, when up to $1.0 \mathrm{~g}$ daily is ingested from a diet rich in fruits and vegetables [20].

Apoptosis is a major form of cell death and essential for normal development and for maintenance of homeostasis. In addition, current anti-neoplastic therapy, chemotherapy and radiation therapy are likely to be effected by the apoptosis tendencies of 
cells, thus, this process has obvious therapeutic implication [21]. The ability in inhibition or in enhancing apoptosis by plant extracts depends on several factors such as; extract concentration and concerted action of multiple micronutrients, cell type [22].

Recently, ginger root and its main poly-phenolic constituents (gingerols, zerumbone) have been shown to inhibit of the transcription factor (Nuclear Transcription Factor Kappa- $\beta$ ) [23]. NF- $\mathrm{B}$ plays an important role in tumorigenesis, having ability to control the expression and function of numerous genes involved in cell proliferation, sustained angiogenesis, and evasion of apoptosis. Different tumor types, including ovarian cancer, have been shown to express high constitutive NF- $\kappa \mathrm{B}$ activity [24]. Reports indicate that ginger component 6- shogaol induces cell death in chemo resistant hepatoma cells [25], yet inhibits cell death in non-neoplastic spinal cord cells [26], suggesting that ginger and ginger components' effects are cell type specific. The apparent contradictory findings may be due to a differential effect of ginger on transformed cells (i.e. cancer cells) vs. untransformed cells. Phytochemicals such as gingerol, generally have multiple molecular targets. This pleiotropism may constitute an advantage in the treatment of ovarian cancer, where multiple factors contribute towards the carcinogenic process. [6]-gingerol treatment exhibited considerable cytotoxicity as indicated by growth inhibition A431 cells mediated via generation of reactive oxygen species (ROS). Increase in ROS led to decrease in mitochondrial membrane potential (MMP) and subsequent induction of apoptosis. Results of the study by [27] suggested that perturbation in mitochondrial membrane are associated with deregulation of $\mathrm{Bax} / \mathrm{Bcl}-2$ ratio at gene transcriptional level as well as protein level, where treatment with [6]-gingerol leads to up-regulation of cytochrome-c and Apaf-1 subsequently culminating in triggering of caspase cascade. These firmly suggest that [6]-gingerol can be effectively used for the treatment of skin cancer. The ethanolic crude extract of Z.Officinallae rhizome was active against cell line growth; successful prediction of crude extracts from plant material is largely dependent on the type of solvent used in the extraction procedure [28]. Crude samples from thousands of species of roots, fruits, leaves or barks from plants have been put through a rigorous series of tests to identify anti-tumor activity. When the extracts showed activity, the extract were purified and active compounds were isolated for study. The relative proportion between the amount of plant used for extraction and crude product was variable depending on several factors, such as method of extraction and solvent used in the extraction presses as well as the type of study plant [29].

\section{References}

1. World Health Organization. (2006). National Cancer Control Programmers. Geneva.

2. Balachandran, S.; Kentish, S.E. and Mawson, R. (2006). The effect of both preparation method and season on the super critical extraction of ginger, J. Purif. Technol. 48: 94-105.

3. Kundu, J. K.; Na, H. K. and Surh, Y. J. (2009). Ginger-Derived Phenolic Substances with Cancer Preventive and Therapeutic Potential. J. Chemoprevention and Cancer. National Research Laboratory of Molecular Carcinogenesis and Chemoprevention, College of Pharmacy, Seoul National University, Seoul, South Korea. 61: 182-192. 
4. Ali BH, Blunden G, Tanira MO, Nemmar A. (2008). Some phytochemical, pharmacological and toxicological properties of ginger (Zingiber officinale Roscoe). J. American Botanical Council. Food. Chem. Toxicol. 46: 409-420.

5. Minigh, J; Garner-Wizard, M; Henson, S; Oliff, H. S; Milot, B; Oppel, M. (2008). Ginger (Zingiber officinale). J. The American Botanical Council. Pp: 30285-357.

6. Kim, SO.; Kundu, JK.; Shin, YK.; Park, JH.; Cho, MH.; Kim, TY.; Surh, YJ. (2005). 6 Gingerol inhibits COX-2 expression by blocking the activation of p38 MAP kinase and NF-kappaB in phorbol esterstimulated mouse skin. J. Oncogene. 24: 2558-2567.

7. Al-Qadoori, J.F. (2004). Effect of some local plants on normal and cancer cells in vitro. Ph.D. Thesis. College of Science. Al-Nahrain University. Baghdad, Iraq.

8. Al-Jeboory, A. (1994). Natural pharmacology, the future of medical plant in drug and medicine industry. $1^{\text {st }}$ ed. Baghdad. Dar Al Huria press. p.75.

9. Harborne, J. B. (1984). Phytochemical Methods. $2^{\text {nd }}$ ed. Chapman and Hall, London. p. 5.

10. Al-Mohammed, N.T.; Al-Rawi, K.M.; Younis, M.A. and Al-Morani, W.K. (1986). Principle of Statistics. J. Al-Mousl University. Iraq.

11. Kathi, J.; Kamper, MD, MPH. (1999). Ginger (Zingiber officinale) The Longwood Herbal task force and the center for Holistic pediatric Education \& Research. Pp: 1-18.

12. Sugden, D. and Davidson K. (2004). "Melatonin, melatonin receptors and melanophores: a moving story". Pigment Cell Res. 17: 454-460.

13. Kim, SO.; Kundu, JK.; Shin, YK.; Park, JH.; Cho, MH.; Kim, TY.; Surh, YJ. (2005). 6Gingerol inhibits COX-2 expression by blocking the activation of p38 MAP kinase and NF-kappaB in phorbol esterstimulated mouse skin. J. Oncogene. 24: 2558-2567.

14. Jayakumar, S.M. and Nalini, R. (1999). Antioxidant activity of ginger Zingiber officinale in rats fed a high fat diet. J. Med. Sci. Res.. 327: 341.

15. Padma, V.V.; Christie, S.A.D.; Ramkuma, K.M. (2007). Induction of Apoptosis by Ginger in HEp-2 Cell Line Is Mediated by Reactive Oxygen Species. J. Basic and Clinical pharmacology and toxicology. Tamilnadu. India. 100: 302-307.

16. Sa'eed, O.F. (2004). The effect of green and black tea extracts on different cell lines in vitro. M.Sc. Thesis. College of Pharmacy. University of Mosul, Iraq.

17. Combest. W.L. (2007). Herbal pharmacy: Ginger pharmacology. Campbell University school of pharmacy, Greek, NC.

18. Li, Y. M.; Ohmo, Y.; Minatoguchi, S.; Fukuda, K. and Fujiwora, H. (2003). Extracts from the roots of Lindera strychifolia induces apoptosis in lung cancer cells and prolongs survival of tumor. Wearing mice. Am. J. Clin. Med. 31: 857 - 869.

19. Surh, Y.J.; Lee, E. and J.M. Lee. (1998). Chemoprotective properties of some pumgent ingredients present in red pepper and ginger. J. Mut. Res.. 402: 259-267.

20. Gulcin, I., M. Oktay, O.I. Kufrevioglu and A. Aslan. (2002). Determination of antioxident activity of lichen Cetraria islandica (L.) Arch. J. Ethnopharmacol. 79: 325-329.

21. Green, D.R.; Bissonnette, R.P. and Cotter, T.G. (1994). Apoptosis and cancer. J. Principles Practice Oncology. 8: 1-14.

22. Palozza, P., S. Serini, F. Di Nicuolo and G. Calviello. (2004). Modulation of apoptosis signaling by carotenoids in cancer cells. J. Arch. Biochim. Biophys. 430: 104-109. 
23. Aktan, F.; Henness, S.; Tran, V. H.; Duke, C.C.; Roufogalis B.D. and Ammit AJ. 2006. Gingerol metabolite and a synthetic analogue Capsarol inhibit macrophage NF-kappaBmediated iNOS gene expression and enzyme activity. J. Planta Med. 72: 727-734.

24. Pacifico, F. and Leonardi A. (2006). NF-kappa B in solid tumors. J. Biochem Pharmacol. 72:1142-1152.

25. Chen CY.; Liu TZ.; Liu YW.; Tseng WC.; Liu RH.; Lu FJ.; Lin YS.; Kuo SH. and Chen CH. (2007). 6-shogaol (alkanone from ginger) induces apoptotic cell death of human hepatoma p53 mutant Mahlavu subline via an oxidative stress-mediated caspase-dependent mechanism. J. Agric Food Chem. 55: 948-954.

26. Kyung KS; Gon JH; Geun KY; Sup JJ; Suk WJ and Ho KJ (2006). 6-Shogaol, a natural product, reduces cell death and restores motor function in rat spinal cord injury. Eur. J. Neuro. Sci. 24(4): 1042-1052.

27. Nigam N.; Bhui, Prasad S.; George and Shukla Y. (2009). 6- Gingerol induces reactive oxygen species regulated mitochondrial cell death pathway in human epidermoid carcinoma A431 cells. J. Chemico-Biological Interaction. India Institute of toxicology Research (CSIR). 5: 302-310.

28. Parekh, J. and Chanda, S. (2006). In vitro Antimicrobial activities of extracts of Launaea procumbens Roxb. (Labiateae), Vitis vinifera L. (Vitaceae) and Cyperus rotundus L. (Cyperaceae). African journal of Biomedical Research. 9: 89-93.

29. Henning, S.M.; FajardoLira, C.; Lee, H.W.; Youssefian, A.A.; Go, V.L.W. and Herber, D. (2003). Catechine content of 18 teas and a green tea extract supplement correlates with the oxidant capacity. J. Nutrition and Cancer. 45:226-235. 